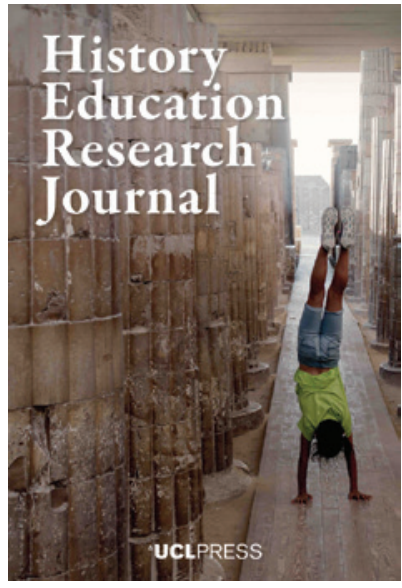

${ }^{\Perp}$ UCLPRESS

HISTORY EDUCATION RESEARCH JOURNAL

ISSN 2631-9713 (Online)

Journal homepage:

https://www.uclpress.co.uk/pages/history-educationresearch-journal

\title{
Editorial: Understanding the role of experience(s) in history education research
}

Andreas Körber (iD and Andy Pearce (iD

\section{How to cite this article}

Körber, A. and Pearce, A. (2021) 'Editorial: Understanding the role of experience(s) in history education research'. History Education Research Journal, 18 (1), 1-6. https://doi.org/10.14324/HERJ.18.1.01

Publication date: 20 April 2021

\section{Copyright}

(C) 2021 Körber and Pearce. This is an open-access article distributed under the terms of the Creative Commons Attribution Licence (CC BY) 4.0 https://creativecommons.org/licenses/ by $/ 4.0 /$, which permits unrestricted use, distribution and reproduction in any medium, provided the original authors and source are credited.

\section{Open access}

The History Education Research Journal is a peer-reviewed open-access journal. 


\title{
Editorial: Understanding the role of experience(s) in history education research
}

\author{
Andreas Körber* - Universität Hamburg, Germany \\ Andy Pearce ${ }^{\dagger}-$ University College London, UK
}

For learning to be both successful and meaningful, it is essential that all those involved in the learning process have a reasonably clear and mutually compatible understanding of how the subjects and themes being studied are relevant, and why they have significance. Accordingly, for those engaged in didactics, the ideas and concepts that learners bring with them - together with their understandings of why a particular learning activity may (or may not) be valuable - are of particular interest and import.

However, any notion that the purposes of learning are given or preordained, and can therefore be simply transmitted to learners, falls far short of the mark. School learning always takes place within a complex mixture of intertwined interests and ideas held by a range of persons; some of these complement each other, while others stand in tension. This reflects the societal dimensions of learning, as an activity involving various groups and institutions, including both teachers and learners.

The task of social reflection, and the negotiation of the reasons and purposes of (school) learning, is thus complex and, due to general social change and the constant succession of new generations of participants, never complete. This is as it should be. New generations of learners must be able to open up the world anew with their own questions and interests, and to think beyond the existing spectrum of concepts and positions, as well as the underlying perceptions, ideas and also conflicts (see Girmes, 1997). This understanding of 'world as task' follows Hannah Arendt's vita activa and concept of education as enabling the independent development of tasks and approaches to solutions that go beyond that which is predetermined by the respective adult generation (Girmes, 1997). It corresponds to a certain extent with Wolfgang Klafki's (2007) conception of the 'mutual development' of subject and world (or reality), insofar as the interest of the respective, already established, adult generations in the questions and perspectives brought in by newly growing learners are also understood as a constitutive element of education.

Against this background, didactic interest in both students' motivation to learn and their notions of relevance and meaning is not limited to the extent to which they share, or have already acquired, norms and beliefs that are elaborated or controversial in wider society. It must also extend to how learners develop their own and broader interests, world views, perceptions of problems in the context of their learning, and acquisition of the respective general and subject-specific concepts and rationales. This means that, in addition to general philosophical and theoretical reflections, empirical exploration of the action-guiding concepts that are active in learning processes are therefore an essential facet of subject didactic research.

If this reality accounts for why research traditions have been established for a long time on the epistemic concepts (in a broader sense) of different groups involved in learning processes, it does not necessarily explain the particular shapes of these traditions across different subjects. A case in point is history, a subject which seems 
to be distinguished from others by its significance as a dimension of public life, as a field of academic research, and as an object of school learning. Perhaps because of this multidimensional functionality, it is subject to, and also necessarily requires, incessant reflection and discussion. It is not sufficient to answer questions about the spectrum of epistemic ideas, or the reasons for researching learning in history in a general or generalizing way - say, for example, purely by means of quantitative empirical approaches. Rather, for didactic action to have concrete effect in teachinglearning processes, empirical explorations of learners' ideas must be accompanied by examination of experiences of learning and of learners' development.

The contribution by Dan Nuttall is indebted to this twofold approach. As a point of departure, Nuttall takes Terry Haydn and Richard Harris's research (2010) on learners' conceptions of the purpose, value and meaning of learning history. Nuttall's interests lie in how far Haydn and Harris's findings are borne out among the students he teaches, and in what positive impact might be made upon students' perceptions of history through a carefully designed intervention. Having established students' preconceptions by way of having them craft a hundred-word statement on the purpose of studying history, Nuttall's intervention centred upon students engaging with material intended to introduce them to a broader discussion about the uses and value of history. This exercise was then in turn to be drawn upon by students as they returned to interrogate their initial statements of the purpose of history, re-evaluating and reshaping their thinking as they saw fit.

Nuttall's findings are noteworthy on multiple counts. In the pre-study, for example, he finds students do not perceive history as having a bearing or connection to identity construction, and that students understand the value of history in intrinsic terms, rather than on a basis of enhancing employability. Meanwhile, following the intervention, Nuttall finds through qualitative analysis a shift towards seeing the possibilities of history as a means of supporting both personal and collective identity formulation and the emergence of epistemological considerations on the interrelation of past, present and future. Needless to say, these are powerful shifts, indicative, Nuttall argues, 'that an impact can be made on the breadth and complexity of students' understanding about the purpose of studying history within a fairly short space of time' (p.105).

Elsewhere, the interest of Tessa de Leur and her colleagues in learning experiences centres specifically on ways in which the historical imagination can potentially be harnessed in history education. De Leur et al. take as an exploratory case study the use of a drama exercise by a group of 14-15-year-old Dutch students learning about the Cold War. In an attempt to cultivate these students' empathetic understanding of how the Cold War impacted the daily life of people in the Netherlands, students were tasked with devising a short film that relayed the experience of a teenager one afternoon during the Cuban missile crisis. To help them, the students were provided with an array of source material and guidance all of which was duly found to have fed through into the students' final dramatic creations. Having these sources was probably a key reason why students felt that they had 'come closer to the past' and tapped into the imagined sensations of those who lived at this moment in history. A similar thing may be said of students' positive level of engagement with the activity, which no doubt owed much to how the drama task encouraged a bringing together of the affective and the cognitive in creative ways. Still, the findings of De Leur and her colleagues in relation to the limitations of the task provide food for further thought, both in terms of how young people experience encounters with the past, and their experience of activities designed to inculcate such engagements. 
Reflecting on student experiences and the experience of students in history education cannot be divorced from explorations of pedagogy. In that sphere, teachers' ideas and beliefs require particular attention - especially in terms of what bearing these have on the learning activities that are constructed. In their contribution,

Súsanna Margrét Gestsdóttir and her colleagues shine a light on these matters by examining how teachers' attitudes towards the development of historical thinking and reasoning in their students do or do not translate into practice. Itself part of a larger study, Gestsdóttir et al.'s paper recounts an empirical investigation into a small group of Icelandic teachers, with whom they deployed an intriguing 'observational instrument', which they call Teach-HTR, in order to surface 'the teaching of historical thinking and reasoning (HTR) in observable teacher behaviour' (p.46). As they note, exploring the development of historical thought among young people has much contemporary currency internationally, but - critically - the degree to which historical thinking is in vogue is no guarantee of its teaching in classrooms. Indeed, Gestsdóttir and her colleagues discovered that this was very much the case in the course of their research, finding as they did that teachers' overarching beliefs about school history, its aims and purposes not only influenced how likely they were to teach in pursuit of historical thinking, but also the nature of the activities they employed. Importantly, however, beliefs and ideas were not the sole determinant of whether a teacher calibrated his or her classroom towards developing students' historical thinking and reasoning. Other notable factors and forces which exerted influence included experiences of initial and in-service training, and the broader curriculum frameworks within which teachers operated.

The translation of beliefs into practice - and the effect this has in shaping learners' experiences in history education - is an area of knowledge and understanding which could benefit from further research. An element that might well warrant much greater scrutiny is the language that teachers employ and the narratives they construct in the classroom. The potential for exploring these matters is illustrated by Charley Brooks in her paper for this issue. Taking the teaching of the 1954 Brown v. Board of Education of Topeka court case in the USA as her focus, Brooks utilizes the tools of critical discourse analysis to study how a small group of teachers frame and narrate this landmark event. Brooks's finding of convergence and commonality in teacher representations coexisting alongside divergence and discursive difference is noteworthy, and in attributing this to 'teachers' larger sentiments about their responsibilities, the purpose of teaching, and meanings of race in the United States' (p.22), Brooks echoes insights put forward by Gestsdóttir et al. Arguably a far more troubling finding, however, is Brooks's discovery that 'White hegemonic discourses circulate in alignment with and in spite of teachers' stated views about teaching history' (p.22). As she explains, this raises multiple questions, in part as it complicates presumptions that students' learning experiences in the virtues of tolerance and antiracism can necessarily be engineered by curriculum diversity or multi-perspectivity in teaching approaches. Indeed, Brooks's suggestion that teachers themselves need to reflect upon their own implicit biases, and those postulated in the narratives they forward, has application much beyond the confines of just American history education.

In addition to Brooks, two more authors use the concept of '(multi-)perspectivity' in their contributions, and they characterize it in quite different ways as a 'threshold concept' - a category hardly used in the discipline, in contrast to the diversely, but not uniformly, used 'multi-perspectivity'.

In her contribution, Maria Johannson identifies the recognition of (multiple) foreign perspectives in learning processes that are understood as 'navigation', when 
confronted with unfamiliar stories, and historical artefacts and narratives as thresholds that indicate progress. She reports on a project focusing on specific intercultural history teaching and learning experiences. With the increasing (or increasingly recognized) diversity and plurality of societies both at state level and globally, her research explores the concrete processes that students apply within teaching concepts in the development of their abilities to recognize and address diversity, both in perspectives on the past and in narrative meaning making. Using the matrix of intercultural history education perspectives developed by Kenneth Nordgren and herself in a previous project (Nordgren and Johansson, 2015), she interprets the classroom activities and (in-between) outcomes of students in specifically designed teaching concepts in two classes as their efforts of exploring new and - conceptually and with respect to their identities - 'liminal' (intellectual) spaces of historical orientation. Thus, historical learning is neither conceptualized nor researched as a process of acquiring substantive and conceptual knowledge (accompanied by the honing of disciplinary 'skills' or competencies), but rather as more or less open operations of (individual and collaborative) mental orientation and meaning making initiated by confrontation with unfamiliar and even unsettling contexts and artefacts. By reconstructing the students' 'navigations' within and across the liminal spaces of meaning as narratives via interview material and observations, and by reconstructing it as a narrative herself, Johansson identifies barriers and junctures which she conceptualizes as thresholds for developing students' historical consciousness beyond their immediate lifeworld. Implicitly, the Nordgren/Johansson matrix evolves as a tool for identifying and conceptualizing interconnected thresholds, not only within empirically observed learning processes, but also with a view to constructing and evaluating related learning opportunities.

In a more theoretical contribution, Javier Paricio addresses the problem of perspectivity in history education explicitly. In response to the problems associated with (naive) realism as an epistemological basis, he reconfirms a reflective epistemology for conceptualizing historical thinking as a prerequisite not only for research, but specifically for learning and teaching historical thinking. Many concepts within this well-established foundation are, he posits, directly related to an underlying concept of 'perspective', be it directly in concepts, aims and methods as 'perspective taking' and 'empathy', or more generally as a central part of historical epistemology. In keeping with the assertion of historical thinking being not merely 'natural' (alas, in a more general sense than in Wineburg's (2001) case), Paricio posits that this 'perspectival epistemology' of history needs to be learned, and for this purpose he suggests a typology of four 'versions' (or dimensions?) of perspectivity, the mastery of which, according to him, is a prerequisite for non-naive knowing of history. Explicitly covering and discussing them in class, therefore, may be regarded as acts of broaching, and potentially breaching, thresholds, opening up more elaborate forms of theoretical insight into the nature of history, and inculcating the ability to actively (and consciously) explore not the past as a given entity, but history as its relation to present and future. How far this suggestion of perspectivity as a (set of) threshold concept(s) can indeed be considered as an element in the context of longer-term models of progression in historical understanding needs to be further discussed, not least in view of the diversity of applications of this concept in the discipline.

Not only is its characterization as a threshold concept therefore worthy of further exploration and discussion, but so too is the understanding of 'perspectivity' itself (see also Stradling, 2004). Because of its metaphorical nature, it is not surprising that transferring principles from optics or painting to the field of history leads to a certain variety and diversity in how perspectivity is understood, and which aspects of historical 
thinking and cognition are to be designated or opened up. However, it is desirable to distinguish this diversity in a more transparent way, and to further clarify the respective professional problems and argumentations.

While the concept of 'historical perspective' in the Canadian 'Big Six' (Seixas and Morton, 2013) focuses on the relevance of differentiating between the perspectives of past actors and those of present perspectives on the past, as well as of interrelating them rather than overcoming the latter, the concept of 'multi-perspectivity' has gained some prominence in German history didactics since the 1980s (Lücke, 2012, based on Bergmann, 1994, 2000). Here, it forms a central principle for designing learning environments and materials, as well as for structuring learning operations and tasks. To this end, it has been differentiated into three facets, referring to the demand for recognizing and reflecting social and cultural diversity: (1) within the past, and for reflecting it in the selection of primary materials ('multi-perspectivity in the narrow sense'); (2) in retrospective references to a past phenomenon, for example, by presenting diverse historiographical accounts and argumentations ('controversiality'); and (3) within today's interests in, and uses of, the past ('plurality') - including the demand to acknowledge (a certain) diversity and plurality of students' perspectives and argumentations.

Our own experience demonstrates that it is difficult for student teachers, among others, to characterize it. At times, for example, the specific derivate of 'multi'perspectivity is addressed as a 'method', then again, as a knowledge or insight to be taught to students, but rather rarely as a principle for research and for the design of learning environments and materials that follows from the epistemological insight into the perspectival nature of all historical statements. Beyond these different meanings associated with the term, then, its status and function within history education must be examined.

These multiple, and by no means uniform, references to 'multi-perspectivity' as a (at least presumably) central concept can be taken as an occasion to explicitly put it up for discussion in the international and intercultural framework of our journal. As indicated in the call for papers for the present issue, we therefore would like to invite you to contribute to a kind of debate in the form of a special series on the concept(s) of perspectivity, its understandings and usages. In particular, we are keen to foster dialogue about concepts, approaches and methods from and within different national, lingual, theoretical and methodological backgrounds or specialisms. We are especially interested in those concepts, approaches and methods that are commonly used or referenced, but which may well have different connotations and meanings in very different contexts. It strikes us that much needs to be discussed - and possibly clarified - about how common ideas, ways of doing things, and points of reference actually operate and function at different times, in different spaces.

Contributions in the form of short, focused articles, can highlight both established understandings and usages of the concepts, as well as the capacities and limits for theorizing and researching historical learning and teaching. They may, but need not, explicitly reference the articles in this issue using and characterizing the concept. The discussion will - hopefully, and dependent upon incoming contributions - stretch over the next two or three issues of HERJ, beginning with issue 18.3. If you would like to contribute, please indicate this in any paper you submit for consideration.

\section{Articles published in this issue of HERJ}

Brooks, C. (2021) 'Discursive differences in teaching the Brown v. Board of Education of Topeka decision and the preservation of narratives of American progress'. History Education Research Journal, 18 (1), 7-27. https://doi.org/10.14324/HERJ.18.1.02. 
De Leur, T., Van Boxtel, C. and Huijgen, T. (2021) '"No, no, the Cold War was not that dramatic": A case study on the use of a drama task to promote Dutch secondary school students' historical imagination'. History Education Research Journal, 18 (1), 28-45. https://doi.org/10.14324/ HERJ.18.1.03.

Gestdóttir, S.M., Van Drie, J. and Van Boxtel, C. (2021) 'Teaching historical thinking and reasoning: Teacher beliefs'. History Education Research Journal, 18 (1), 46-63. https://doi.org/10.14324/ HERJ.18.1.04.

Johansson, M. (2021) 'Moving in liminal space: A case study of intercultural historical learning in Swedish secondary school'. History Education Research Journal, 18 (1), 64-88. https://doi. org/10.14324/HERJ.18.1.05.

Nuttall, D. (2021) 'What is the purpose of studying history? Developing students' perspectives on the purposes and value of history education'. History Education Research Journal, 18 (1), 89-108. https://doi.org/10.14324/HERJ.18.1.06.

Paricio, J. (2021) 'Perspective as a threshold concept for learning history'. History Education Research Journal, 18 (1), 109-25. https://doi.org/10.14324/HERJ.18.1.07.

\section{Notes on the contributors}

Andreas Körber has been Professor for Education with special regard for history and political education at Universität Hamburg since 2004. He worked as a research assistant from 1993 to 1997, and completed his PhD in history in 1999. He was a schoolteacher between 1999 and 2005. His research interests are in theoretical and empirical research in history education, with a focus on historical consciousness, competencies of historical thinking, history and memory culture, and intercultural and inclusive history education.

Andy Pearce is Associate Professor in Holocaust and History Education at University College London, UK. He is the author of Holocaust Consciousness in Contemporary Britain (Routledge, 2014), editor of Remembering the Holocaust in Educational Settings (Routledge, 2018), co-editor of three collections, including The Palgrave Handbook on Britain and the Holocaust (Palgrave Macmillan, 2020), and co-author of the school textbook Understanding the Holocaust (Hodder Education, 2020). He works in teacher education and is a historian of Britain and the Holocaust.

\section{References}

Bergmann, K. (1994) 'Multiperspektivität'. Geschichte in Wissenschaft und Unterricht, 45 (3), 194-8.

Bergmann, K. (2000) Multiperspektivität: Geschichte selber denken. Schwalbach/Ts: WochenschauVerlag (Wochenschau Geschichte).

Girmes, R. (1997) Sich zeigen und die Welt zeigen - Bildung und Erziehung in posttraditionalen Gesellschaften. Bildung und Erziehung in posttraditionalen Gesellschaften. Wiesbaden: VS Verlag für Sozialwissenschaften.

Haydn, T. and Harris, R. (2010) 'Pupil perspectives on the purposes and benefits of studying history in high school: A view from the UK'. Journal of Curriculum Studies, 42 (2), 241-61.

Klafki, W. (2007) 'Grundlinien kritisch-konstruktiver Didaktik'. In Klafki, W. (ed.), Neue Studien zur Bildungstheorie und Didaktik: Zeitgemäße Allgemeinbildung und kritisch-konstruktive Didaktik. 6th ed. Weinheim: Beltz (Studium Paedagogik), 83-138.

Lücke, M. (2012) 'Multiperspektivität, Kontroversität, Pluralität'. In Barricelli, M. and Lücke, M. (eds), Handbuch Praxis des Geschichtsunterrichts: Historisches Lernen in der Schule. Schwalbach/Ts.: Wochenschau-Verlag (Wochenschau Geschichte), 281-8.

Nordgren, K. and Johansson, M. (2015) 'Intercultural historical learning: A conceptual framework'. Journal of Curriculum Studies, 47 (1), 1-25. https://doi.org/10.1080/00220272.2014.956795.

Seixas, P. and Morton, T. (2013) The Big Six Historical Thinking Concepts. Toronto: Nelson Education.

Stradling, R. (2004) Multiperspectivity in history teaching: A guide for teachers. Strasbourg: Council of Europe. https://rm.coe.int/1680493c9e (accessed 13 January 2021).

Wineburg, S. (2001) Historical Thinking and Other Unnatural Acts: Charting the future of teaching the past. Philadelphia: Temple University Press. 